\title{
Familial episodic pain syndrome
}

INSERM

\section{Source}

INSERM. (1999). Orphanet: an online rare disease and orphan drug data base. Familial episodic pain syndrome. ORPHA:391384

Familial episodic pain syndrome is a rare, genetic, peripheral neuropathy disorder characterized by recurrent, stereotyped, episodic intense pain, ocurring predominantly in either the upper body or lower limbs in several members of a family, which is triggered or exacerbated by fatigue, cold exposure, fasting, weather changes and/or physical stress or exertion and may or may not diminish with age. Sweating and other manifestations, such as tachycardia, breathing difficulties and generalized pallor, may be associated. 